\title{
FACT OR MYTHOLOGY - YORUBA AND BENIN HISTORICAL CORRELATION
}

\author{
O. S. Osadola ${ }^{1 *}$, O. M. Olofinsao ${ }^{2,}$ I. O. Ajisafe ${ }^{3}$ \\ ${ }^{1}$ Department of History and International Studies, Federal University, Oye Ekiti, Nigeria, oluwaseun.osadola@,fuoye.edu.ng \\ ${ }^{2}$ Department of Linguistics and Languages, Federal University Oye Ekiti, Nigeria, olukemi.olofinsao@fuoye.edu.ng \\ 32Department of Linguistics and Languages, Federal University Oye Ekiti, Nigeria, iyabo.ajisafe@fuoye.edu.ng
}

\begin{abstract}
Indisputably, the origins of peoples and races are controversial, and that of the Binis' and the Yorubas is no exception. Organizationally, the Benin monarchy was structured to command the respect and loyalty of the Benin people and the envy of other ethnic nationalities. This drew the Portuguese, the first trans-Atlantic foreigners, to the ancient kingdom for exploratory and commercial purposes. The loyalty of the Binis towards the sustenance of the Benin Monarchy; its precious artefacts and cultural attributes is an expression of nationalism. This singular concept explains her imperialistic actions in north-eastern Yoruba land. The controversy attached to the historical origin of the Bini people linked with the Yoruba people is worthy of note. The Yoruba's allegiance to Ile-Ife as the cradle of their race aligns with Oduduwa's stead and civilisation. This intergroup relationship has brought about cultural similarities between the people of Benin and Yoruba, noting the position of Oranmiyan. This has necessitated a review into the dialogue-dispute that exists among history scholars of both derivations as to the point of link and level of relationship that had existed among them. The study's position is curled from the existing historical facts. Using both primary and secondary sources, the study examines the historical narrations of scholars in assessing and establishing facts as to the relationship between them.
\end{abstract}

Keywords: Myth, Yoruba, Ile-Ife, Benin, History, Ogiso, Correlation

\section{INTRODUCTION}

The pre-classical body of knowledge was founded on speculation rather than observational evidence. Hegel's history theory is a subset of psychology, and the question confronting its representative is that it traces the operation of reason in a particular scientific domain. ${ }^{1}$ In creating the earth, the causal interpretation of rain and Dove sounds more mythical than fact. It is a speculative historical explanation similar to fable and mythology. Regarding the mythological awareness of the past, Lemon opines that though very few important literature from ancient Egypt, Greece and others in the Middle East are presently surviving, scientists have discovered sufficient information to create records on or at the very least suggest how these cultures "understood the past." There are three distinguishing characteristics: a legendary conception of time and space; a belief in the eternal recurrence of 'waves of events'; and a lack of understanding of man's historical capacity to form what he called 'alter.'

The above characteristics contradicted the Yoruba race's legendary tale of 'elédùmarè' (The Supreme Being) rain and Dove creation. According to archaeological evidence, the Oduduwa dynasty is about two thousand (2000) years in span, which suggests some cultures flourished prior to his arrival. ${ }^{3}$ Erediauwa ${ }^{4}$ who opposed Egharevba's ${ }^{5}$ position

\footnotetext{
${ }^{1}$ W. H. Walsh., An Introduction to Philosophy of History. (Hutchinson's University Library, 1951) p. 142

${ }^{2}$ M. C. Lemon, Philosophy of History: A Guide for Students. (Routledge, 2003) p. 16

${ }^{3}$ S. O. Johnson., The History of the Yorubas, London: Lowe and Brydone Printers Limited, 1921, p. 35
} 
on the origin of the people of Benin couldn't simply show the origin of the people of Benin despite his refusal to accept the narrative that they originated from the Yoruba people. ${ }^{6}$ This research is supported by the debate around historical theories and explanations and the relations between Benin and Ile-Ife (the Cradle of the Yorubas) about the Yorubas' and Binis' views and associations. This study will further assess the narratives of three major scholars whose works on Benin and Yoruba history are somehow contrasting. This will help assess the changes and similarities in their narratives in order to contribute a valid update to the existing dialogue.

\section{HISTORICAL REVIEW}

\section{Benin: City of the Ancestors}

Benin (Bini) in southern Nigeria has been described as the City of Love, the Land of Vexation, Land of the Powerful Oba and Great Benin. It's incredible bronze and ivory artwork astounded a late 19th-century western world still in denial of black African civilisation. ${ }^{7}$

Linguists calculate that Edo-speakers ancestral to Benin began shifting south to the rainforest some 8,000 years ago. ${ }^{8}$ About 2,000 years ago, iron technology and plantain cultivation helped the population grow sufficiently to sustain permanent communities, which dug vertical-sided ditches around their farmlands as protection against nocturnal devastation by forest elephants. So began a vast $16,000-\mathrm{km}(10,000-\mathrm{mile})$ long earthen record of settlement growth over time. ${ }^{9}$

This record shows that, around 1,000 years ago, land shortages triggered a migration westwards; by the 13th century $\mathrm{AD}$, the new settlements encompassed the territory to become Benin. The migrants brought their ancient beliefs linked to the rural cultural landscape, where new villages planted 'everlasting' ikhimwin tree shrines before any house-building, farming, or sexual congress could begin. ${ }^{10}$ Their linear earthworks separated the natural world from the spirit world and were crossed only by women. Regional cults based around hero-deities (ihen) characterized the petty chiefdoms. Benin, for example, initially accepted the ihen of its incoming migrants, contributing to its global success. The leaders of Benin also created a solid spiritual power base of their own, centred on shrines featuring socalled potsherd pavements and deep iha pits to hold those sacrificed to the earth. ${ }^{11}$

Benin's potsherd pavements may connect it to the common myth of state formation centered on Ife's sacred city and herald the late 13 th century Oba dynasty. ${ }^{12}$ This dynasty, governed by kings considered divine, had its snake worship palace and other practices that strengthened the dynastic mystic influence. Radiocarbon dates in the towns of Benin and its rivals, Udo, indicate that the power of both centres was consolidating around the beginning of the 14th

\footnotetext{
${ }^{4}$ Omo N' Oba Erediauwa., I Remain, Sir, Your Obedient Servant, (Spectrum Books Publisher,2004)

${ }^{5}$ J. Egharevba, A Short History of Benin, $5^{\text {th }}$ edition, Ibadan: University Press, 1966

${ }^{6}$ O. S. Osadola et al. Benin-Ekiti Relation: An Onus of Substantiation, Global Scientific Journal, Vol. 7, Issue 2, 2019

${ }^{7}$ R. E. Bradbury., The Benin-Kingdom and the Edo-Speaking Peoples of South-Western Nigeria (London, 1957) see also, G. E. Connah., The Archaeology of Benin (Oxford, 1975)

${ }^{8}$ P. J. Darling., Archaeology and History in Southern Nigeria: The Ancient Linear Earthworks of Benin and Ishan (Oxford, 1984)

${ }^{9}$ P. J. Darling., Archaeology and History in Southern Nigeria...

${ }^{10}$ A. Ben-Paula., The Art of Benin, (London: Thames and Hudson Publishing 1974)

${ }^{11}$ O. S. B. Omoregie., Benin under the Ogiso Monarchy, (Benin City: Neraso Publishers Limited 1988)

${ }^{12}$ O. S. Osadola et al. Benin-Ekiti Relation...
} 
century, coinciding with the 'classical age' of spiritual suzerainty of Ife in the 13th/mid-14th centuries when superb bronzes and terracotta were created. ${ }^{13}$

Oba Ewuare invaded and burned Benin in the middle of the 15th century, casting the ihen of the city and deepening the rampart; burying the charms under the nine gates; and establishing the Executive Council of Eghaevbo n'Ore and the Senior Society of Iwebo to support and respect his divine kingdom's rituals. ${ }^{14}$ His military policy of splitting his forces into nine parts to surround enemies expanded the sphere of control of Benin, capturing thousands of slaves to create an annual tribute to yam and palm oil under provincial leaders. This new organisation fundamentally reorganized Benin.

Europeans from the sixteenth century opposed Benin and its towns, with a rampart of $20 \mathrm{~m}$ deep (66f), spacious streets full of people, vibrant marketplaces packed with food and medicinal items and mud-purged homes walls of snail shells shining like red marble. In addition to recording over 40 working trade organisations dealing in woodcarving, dyeing, weaving, ceramics, blacksmithing, brass casting and mat-making, visitors also recorded that women did the labour all around the middle of the 17 th century, the males sipped palm wine and smoked tobacco. ${ }^{15}$

The Oba Palace, surrounded by a wall of about 6 meters, occupied a large part of the town, which included open-air courtyards and labyrinths, warehouses and women's quarters, centuries-old buildings, polished, pink granite floors and torrents high 12 meters (40 ft.), all with a giant bronze python or a spectacular ibis bronze, with extended eaves. Long galleries have been decorated with splendid bronze plaques, which depict earlier accomplishments and ceremonial activities. ${ }^{16}$

After Oba Ehengbuda drowned in a boat accident in the early 17th century, Obas stopped being a warrior ruler and was confined to more than 200 State rites per year. Spiritual meditation was pursued; fatalities on the large Akpapava Street were exposed; the adjacent castle was lined with skulls. The Benin Epithet City of Blood was falsely given many further sacrifices to avert the British Invasion in 1897. ${ }^{17}$ (Ryder, 1969)

The conquest exposed the inner palace sanctum of ancestral altars. Amid iron handbells and ancient stone, axes were striking bronze heads depicting each past $O b a$ wearing ceremonial red coral necklaces and headgear. On top of each head were enormous ivory tusks, skilfully carved with a timeless iconography, to receive annual offerings. The western world hailed this magnificent 'art'. However, many missed the real significance of Benin: it was the last great African city-kingdom fully practising ancient beliefs in a magical universe - beliefs deriving from the original roots of all humanity's quest for immortality. ${ }^{18}$

\footnotetext{
${ }^{13}$ O. S. B. Omoregie., Benin under the Ogiso Monarchy...

${ }^{14}$ J. J. Norwich., (ed) The Great Cities in History. Thames \& Hudson Ltd, London, 2009

${ }^{15}$ J. J. Norwich., (ed) The Great Cities in History...

${ }^{16}$ P. J. Darling., Archaeology and History in Southern Nigeria... pp. 162-64

${ }^{17}$ A. F. C. Ryder., Benin and the Europeans 1485-1897 (London, 1969) see also F. Willett., 'Ife and its Archaeology', Journal of African History 1, 2 (1960) pp.231-48

${ }^{18}$ P. J. Darling., Archaeology and History in Southern Nigeria
} 


\section{The Yorubas: Ile-Ife to Oyo}

The Yoruba speaking people are an ethnic group that encompasses Southwestern Nigeria, north central Nigeria, south and central Benin-republic. They constitute over forty million (40 million) peoples in total. ${ }^{19}$ They are however one of the largest ethnic groups in the African continent.

As an ethnic description, the word 'Yoruba' was first recorded in reference to the Oyo Empire in a treatise written by the $16^{\text {th }}$ century Songhai scholar - Ahmad Baba ${ }^{20}$. The word was however popularized by Hausa usage 'Yarriba' and ethnography written in Arabic and Ajami ${ }^{21}$ during the $19^{\text {th }}$ century.

The Yoruba nation is located to the immediate west of the River Niger (below the confluence) and to the south of the Quorra (i.e., the Western branch of the same River above the confluence), with Dahomey to the west and the Bright of Benin to the south. ${ }^{22}$

Although they had a similar race and linguistic group, evidence reveals that the African peoples who resided in Yorubaland were not originally recognised as the Yoruba as early as the 7th century BCE. Ile-Ife was already a formidable Yoruba kingdom by the 8th century CE, one of the first in Africa, south of the Sahara-Sahel. ${ }^{23}$ Almost every Yoruba colony may be traced back to Ile-Ife rulers. As a result, Ife might be considered the Yoruba nation's cultural and spiritual home. Ife's habitation may be traced back to the 4th century BC, with urban constructions dating from the 12th century CE. The Oni (or monarch) of Ife claims direct link with Oduduwa.

Between the 12th and 14th centuries, the city was a significant community with homes with potsherd pavements. Ile-Ife is famed around the globe for its ancient and realistic metal, stone, and terracotta sculptures, which peaked in creative expression between the years 1200 and 1400. Around the year 1300, Ife artists developed a refined and naturalistic sculptural tradition in terracotta, stone, and copper alloy - copper, brass, and bronze-many of which appear to have been created under the patronage of Obalufon II, the Yoruba patron deity of brass casting, weaving, and regalia. Production began to wane after this time, as political and economic dominance passed to the adjacent kingdom of Benin, which, like the Yoruba kingdom of Oyo, grew into a great empire. ${ }^{24}$

The mythological beginnings of the Oyo Empire may be traced back to Oranyan (also known as Oranmiyan), the second prince of Ile-Ife, who established Oyo as his new kingdom and became the first Oba with the title of Alaafin of Oyo (Alaafin in Yoruba means "owner of the palace"). ${ }^{25}$ According to legend, he abandoned all of his belongings in Ife and let another monarch, Adimu, to reign there. ${ }^{26}$ Oba Ajaka replaced Oranyan, but he was overthrown

\footnotetext{
${ }^{19}$ E. A. Kenyo., Origin of the Progenitor of the Yoruba Race, Lagos: Yoruba Historical Research Co. 1951

${ }^{20}$ Ahmed Baba was a prominent African intellectual of the sixteenth century. His accomplishments as a prolific writer and Islamic scholar include a legal judgement on slavery and several biographies of notable jurists. During his lifetime, he was noted for his legal treatises dealing with Islamic difficulties and the proper method for Muslims to practise their religion. Ahmed Baba's name is now synonymous with the golden age of Timbuktu. See African Roots., Ahmed Baba: Timbuktu's famous scholar., https://www.dw.com/en/ahmed-baba-timbuktus-famous$\underline{\text { scholar/a-43193451 }}$

${ }^{21}$ The term Ajami, derived from the Arabic root for alien or stranger, refers to an Arabic alphabet used for writing African languages, most notably Hausa and Swahili. Many other African languages, including Yoruba, Fulani, and Pulaar were also written using the script. It is thought to be an African writing system originating from Arabic. Many African languages feature phonetic sounds and systems that are not available in standard Arabic, a customised Arabic script is utilised to transcribe those "foreign" sounds. Iran, South Asia, and Southeast Asia all have adapted Arabic scripts. https://en.wikipedia.org/wiki/Ajami_script

22 T. Falola., Yoruba Historiography, Madison: University of Wisconsin Press, 1991

${ }^{23}$ S. O. Biobaku,. Sources of Yoruba History, New York: Clarendon Press, 1973

${ }^{24}$ E. A. Kenyo., Origin of the Progenitor of the Yoruba Race, Lagos: Yoruba Historical Research Co. 1951

${ }^{25}$ S. O. Johnson., The History of the Yorubas, London: Lowe and Brydone Printers Limited, 1921

${ }^{26}$ Ibid p. 76
} 
because he gave his sub-chiefs too much power. Ajaka's brother, Shango, was subsequently given command, and he was eventually deified as the god of thunder and lightning. After Shango's death, Ajaka was resurrected. Kori, his successor, was able to capture the remainder of what historians eventually referred to as metropolitan Oyo. ${ }^{27}$ Oyo-Ile, the capital of metropolitan Oyo, was its beating heart.

By the end of the 14th century, Oyo had developed into a strong inland power, but it had suffered military losses at the hands of the Nupe, commanded by Tsoede. The Nupe conquered Oyo about 1535, forcing the reigning family to seek sanctuary in the kingdom of Borgu. ${ }^{28}$

As an exiled dynasty, the Yoruba of Oyo had an eighty-year interregnum. They did, however, re-establish Oyo as being more centralised and vast than ever before. Oyo started a lengthy period of expansion in the 17th century, eventually becoming a powerful empire. It was never the most populous Yoruba kingdom, but it was the most populated in Yoruba history. ${ }^{29}$

\section{NARRATIVES BY SCHOLARS ON HISTORICAL LINKS BETWEEN THE BINIS AND THE YORUBAS}

\section{The Tale of Ikaladerhan}

According to Omoregie, Ikaladerhan or Ekaladerhan ${ }^{30}$ lived for about two years as Enogie of Ughoton. Ughoton is a community in present day Nigeria's Edo State that was reportedly founded by Ekaladerhan (son of Ogiso Owodo). ${ }^{31}$ Prince Ekaladerhan was said to be the only child of Ogiso Owodo, the last Ogiso of the Ogiso dynasty who came to the throne in c.1068AD. His reign witnessed the end of Ogiso dynasty. Ekaladerhan mother's name was Imade. She was from a very poor background; hence, she was always despised by other wives because Ekaladerhan's mother was given to Ogiso as a tribute. ${ }^{32}$ Information had reached Oliha in Benin that the Prince was alive, so the Great Nobles were of the hope that upon Owodo's death, they would readily have an heir to link up the succession line. ${ }^{33}$ The executioners had left the Royal Palace to take refuge in Oliha's house so that if the information reached the king that they did not kill Ikaladerhan as ordered, their lives would be spared. The renowned Oraclist, Ewaen, whose story about the harem barrenness was twister to Owodo had travelled to Umaghan 'to add more to his divination art. When he returned and heard of the havoc which Esagho had used his name to do, he went straight to the king to release the actual story. ${ }^{34}$

Meanwhile, Ikaladerhan had left Ughoton for Errua, some 43 kilometres on the Uhunmwade route. His mother, Ometo, had died at Ughoton, and as was usual, her body had to be taken to her place, Errua, for burial. Ikaladerhan knew that if he left Ughoton, his mother's people at Errua would not want him to leave. They would want him to be

\footnotetext{
${ }^{27}$ R. S. Smith., Kingdoms of the Yoruba, Madison: University of Wisconsin Press, 1988

${ }^{28}$ S. O. Biobaku, Sources of Yoruba History, New York: Clarendon Press, 1973

${ }^{29}$ J. A. Atanda., An introduction to Yoruba History, Ibadan, University Press, 1980

30 Wikipedia spelling of Ikaladerhan, www.wikipedia.com/ughoton

31 M. Ediagbonya. An Analysis of The Traditions of Origin of Ughoton: the Seaport of Old Benin Kingdom. International Journal of Trade and Policy, Vol. 1 (7)2018

32 Ibid

33, O. S. B. Omoregie., Great Benin 5: The Age of Ikaladerhan (1130-1200 AD), Benin: Neraso Publishers Limited, 1997

${ }^{34}$ M. Ediagbonya., The Socio-political and Economic Transformation of Ughoton, (Benin Kingdom), ca, 1440-1897, PhD. Thesis presented to the Department of History and International Studies, University of Benin, September, 2015
} 
their Enogie, just as he had been for the Ughotons.He decided to appoint the Ohen-Okun of Ughoton to perform the functions of Enogie in his place. ${ }^{35}$ Thus, the Ohen-Okun became the first Enogie to be created by Ikaladerhan in the course of his post-condemnation flight. The time was about 1129AD. Ikaladerhan's wife, Isere, was expecting a child when he left Ughoton. Upon reaching Errua, ceremonies concerning his mother's burial were performed, and he became the first Enogie of the place; his first son was born. He called the name Omonoyan (i.e. child whose demands are challenging to meet), which according to Omoregie was also Oranmiyan. Such a name was generally given to a child who has cried the parents could not ignore. ${ }^{36}$

The people of Errua were presumed to have been as jubilant at Ikaladerhan's coming to them as the people of Ughoton had been. They have claimed that even till the present day, Ikaladerhan was the founder of Errua. ${ }^{37}$ It is known that if Ikaladerhan's mother was married at Errua in the Royal home in Benin, the founding of the place could not have waited till the coming of the Prince and his first Enogie. Ikaladerhan established the Enogieship of Errua, not the community. ${ }^{38}$

Ikaladerhan learned a few months after Omonoyan's birth (1130 AD) that his father, Owodo, had commissioned a ruler rather than Ogie Ogiso or the Ogiso's sceptred ruler.Ikaladerhan's followers had met him during his first seven days in the Ihinmwirin forest after his life was spared. ${ }^{39}$ For security reasons, they directed him toward Ughoton to avoid the chances of the enemy quickly catching up with him. Neither Ihinmwirin, his father's area, nor Errua, his mother's town, was safe for Ikaladerhan at this time. Ughoton was a neutral place and was beyond easy suspicion. It still exists today as one of the historic towns in Nigeria. It lay some 40 kilometres southeast of Benin and was an overnight walking distance from Benin at that time. ${ }^{40}$

Emissaries immediately left for Ughoton to inform the Odionwere that Ogiso's son was coming to settle in Ughoton and bring the blessings of the royal home to the place. According to the existing tradition, if a royal son decided to or was sent to make a home in Anokace where Odionwere was the head; he would at once be accorded the position of Enogie. ${ }^{41}$ The Odionwere of Ughoton and his people made elaborate preparations to receive Ikaladerhan. When he arrived, he settled with Ohen-Okun (Olokun), the chief priest of the god of the sea. The Avbiogbe were the Enogie's information and peace development officers in Ughoton. As Enogie, Ikaladerhan organised the people into guilds according to the variety of their craft industry. Thus, there developed a group of woodworkers, ironworkers, fishermen, hunters, leather workers, weavers and farmers who gave the artisans pastoral support. He married the daughter of Odionwere of Ughoton and changed her name from Okunhonwa to Isere (meaning, I have survived till today) to commemorate the hardships he passed through before becoming Enogie in Ughoton. ${ }^{42}$

\footnotetext{
${ }^{35}$ Ibid

${ }^{36}$ O. S. B. Omoregie., Great Benin 5: The Age of Ikaladerhan (1130-1200 AD)...

${ }^{37}$ M. Ediagbonya., The Socio-political and Economic Transformation of Ughoton..

${ }^{38}$ O. S. B. Omoregie., Great Benin 5: The Age of Ikaladerhan (1130-1200 AD)...

${ }^{39}$ M. Ediagbonya., The Socio-political and Economic Transformation of Ughoton...

${ }^{40}$ O. S. B. Omoregie., Great Benin 5: The Age of Ikaladerhan (1130-1200 AD)...

${ }^{41}$ M. Ediagbonya., The Socio-political and Economic Transformation of Ughoton...

${ }^{42}$ O. S. B. Omoregie., Great Benin 5: The Age of Ikaladerhan (1130-1200 AD)...
} 


\section{The Tale of Oranmiyan in the Yoruba History}

Oranyan or Orafiyan, Odududuwa's grandson, succeeded his grandpa on the throne according to Samuel Johnson. ${ }^{43}$ He was a courageous and warlike Prince of unshakable courage. He was allegedly transported to a site called Oko when the town of Oyó was established, leaving Oyo in the care of one of the princes. This accusation is not unbelievable considering the unresolved rule of the day and the fact that this warlike Prince tried to extend his domination far and wide. ${ }^{44}$

He had been living in Oko for a few years but his place of death is unknown: some believe he died at Ile-Ife, where his tomb remains visible to this day. ${ }^{45}$ According to Johnson, when a King of Yoruba goes to his hometown, his hair and nails are cut off and taken to the place where his burial takes place.

This, however, may have been Oranmiyan's situation. But, in one account from the latter years, Oranmiyan was forced, after a long reign, to return for too long to the city of Ile-Ife, either to settle some family affairs, or to take over some of the valuables left by his father in the care of Adimu. He left his son Ajaka as Regent. The citizens, having stayed much longer than specified time to return to Oko (communication between the two at that time being riskier and complicated), assumed that he was dead, or that he would never return to Oko at least; Ajaka was confirmed by Oyo Mesi, the city sanctioned governor, with his full royal powers and insignia on his throne. ${ }^{46}$

When Oranmiyan returned to Oko and found that his son Ajaka was taken up as a substantive ruler, his attention was focused on the Kakaki trumpet - a trumpet blasted solely for the Sovereign. When he realised what had happened, he retraced his way gently to Ile-Ife, where he retired happily for the remaining days. To this day, an obelisk known as Opá Oranyan (the staff of Orafiyan) is visible at Ile-Ife near the place where is claimed to have been buried. This tends to corroborate the view that he died and was buried, not Oko, at Ile-Ife. ${ }^{47}$

This obelisk is approximately 10 to 12 feet large and at its base approximately 4 square feet; it tapers to one point and has many spike nails moved onto one side, and various sculptures imitating old characters. The nails are arranged in order to emphasize their importance. There are 61 lines in a line from the bottom upward at roughly 2inch intervals in the midline and then two parallel lines, each flowing downwards and curve downwards to the midline at about 4-inch intervals on either side of the line, and commencing the same level above. The most notable gravures are situated in the area between these three rows of parallel lines, about at the intersection level. ${ }^{48}$

What is most plausible in these arrangements is that the 61 nails in the centre reflect the number of years that Oranyan lived, and that the 31 nail on each side suggest he was 31 years old when he was in office, that he ruled for 31 years, twice that of Yorubas with his year in office. ${ }^{49}$

\footnotetext{
${ }^{43}$ S.O. Johnson, The History of the Yorubas, London: Lowe and Brydone Printers Limited 1921

${ }^{44}$ R. Smith, Kingdom of the Yoruba, London: University Press, 1964

${ }^{45}$ S.O. Johnson, The History of the Yorubas... p. 144

${ }^{46} \mathrm{Ibid}$

${ }^{47}$ S.O. Johnson, The History of the Yorubas... p. 144

${ }^{48}$ S.O. Johnson, The History of the Yorubas... p. 144

${ }^{49} \mathrm{Ibid}$
} 
Oranmiyan was supposed to be a battle hero who eventually collected tributaries from his siblings. He subsequently assigned delegates in each of Yoruba's kingdoms to keep track of the tributaries' returns. The establishment of the Oyo Empire resulted in the demise of Oduduwa's uncoordinated empire. In the south of Sahara, the Yoruba race was accorded great respect and a suitable foundation by the Oyo Empire. The new kingdom spread over West Africa at breakneck speed, emulating the historic Ghana or Shonghai Empire in the Sahara's south..$^{50}$

One of the Oyo Empire's tactics was to engage in slavery. It was a strategic move to diminish dissent among Yorubas and those who had been abducted. Oranmiyan and his successors had complete command and power. In reality, the term "Kabiyesi" 51 was eventually adopted by future Alafin in Oyo from the period of Sango (Oko Oya) indicated absolute monarchy, with the king never being incorrect. Alafin's dread and authority were felt across Yoruba territory. ${ }^{52}$

Oranmiyan's administration was the finest in Africa, and it was comparable to the British administrative system under colonial rule. The Empire grew until it reached the present-day Benin Republic (Present day West Africa). Yorubas residing in Benin Republic, previously Dahomey, are among those who have fled Alaafin's authority. ${ }^{53}$ The cause for this is unknown, but if Oranmiyan is forced to launch a control war over Benin, it will be equivalent to battling oneself. The Oba of Benin, Omo N' Oba Okpolokpolo, did not explain why the Benin-Oyo Empire ceasefire had been extended. ${ }^{54}$ Before any Oba was crowned at Benin, spiritual communication was established with each Benin King's head buried in Ife, as well as spiritual approbation from Ife. Ile Ife was able to display its dominance by possessing Oranmiyan's head. ${ }^{55}$ While Benin Kingdom progressed and the Oyo Empire continued to extend to the west coast, there was no record of any business transaction between father and son or any recorded tribal or communal fighting between Yoruba and Benin Kingdom. There could not be a conflict in Lagos; it was a site of reunion for Edos and Yorubas, since it was known as Eko, or Lagos. ${ }^{56}$

\section{The Tale of Prince Oranmiyan in Benin History}

According to the narration of Jacob Egharevba, Odudua dispatched seven lice to the leaders of Benin (when they came begging for a traditional head) with the instruction that they should be returned after three years. This criterion was intended to ascertain if the people of Benin will be able to care well for whichever of Odudua's son he decides to release to them. The condition was actually satisfied and Odudua was amazed that the lice grew well and healthy

\footnotetext{
${ }^{50}$ S. O. Biobaku, Sources of Yoruba History, New York: Clarendon Press, 1973, p.154

${ }^{51}$ In Yoruba land, the paramount ruler, known as Kabiyesi, which also means Ka bi o o si (To query you, is a non starter), is usually referred to as "Igba Keji awon orisa" (The deputy of the gods, or ancestors). He is a monarch who wielded absolute power! What he wanted, he gets! His words are law, see S.O. Johnson, The History of the Yorubas, London: Lowe and Brydone Printers Limited 1921, p.35 52 Ibid

${ }^{53}$ N.A Fadipe, Sociology of the Yorubas, Ibadan: Ibadan University Press, 1970

${ }^{54}$ Omo N' Oba, Erediauwa, I Remain, Sir, Your Obedient Servant, (Spectrum Books Publisher,2004)

${ }^{55}$ A. F. Ryder., "A Reconsideration of the Ife - Benin Relationship", Journal of African History, Vol. 6, No. 1. 1965

${ }^{56}$ J. K. Olupona., The city of 201 gods: ile-ife in time, space, and the imagination, Berkeley: University of California Press, 2011
} 
when the leaders of Benin returned afterwards. The Oliha of that period, who preserved the lice in one of his slaves's hair, gave him the Ogelemodu or more accurately, 'o gele mom iru,' that is, he preserves a lice. ${ }^{57}$

Egharevba wrote that Odudua gave his son and successor, Obalufon clear orders to send Oranmiyan to the people of Benin. Prince Oranmiyan, one of the children of Odudua, the progenitor of Yoruba race in Ife, was sent with a ferryman to the Ovia River, accompanied by brokers and the local physician Ogiefa. ${ }^{58}$ Ogiamwen, the son and heir of Evian, was firmly against his coming. He rationalised his conduct by saying that serving a monarch 'Ogiemianmwen na ga' was too tough, thus obtaining Ogiamwen's moniker. Since, however, the people thought that they needed a proper Oba; his suggestion was given little consideration.

Prince Oranmiyan resided in the palace that the elders of Usama had built for him (now a coronation shrine). He married Erinmwinde, Osanego's daughter, a gorgeous lady, Onogie's tenth seed, with whom he had a son soon after his arrival. After a few years, he organised a people's gathering and renounced his post, declaring that the area was a country of trouble called "Ile-Ibinu," and only a child, who was born, reared and taught the arts and secrets of the country could control it. He appointed his son, Erinmwinde as Oba and went back to his home country, Ife. ${ }^{59}$

On his way back to Ife, Oranmiyan stopped and settled at Ugha, now Okha, in the northwest of Benin division, where the Binis went to him for decisions in their matters for three years. On one occasion, while they were in a meeting under the cotton tree, Okha in the open air (as the inner court could not accommodate so great a crowd of people), a branch of the cotton tree fell suddenly upon and killed many people in the assembly, and this caused the meeting to close down and Oranmiyan to quickly proceed to Ife. It has been a parable since that Okha n'Ugha yanbo gb'uri-omwan vb 'azagba iko Okha, meaning' a branch of the cotton tree of Ugha fell and killed two hundred people in the open-air meeting of Okha'. The name of the place was afterwards changed from Ugha to Okha, the name of the cotton tree, as a remembrance of that incident. ${ }^{60}$

Oranmiyan also halted at Obbah and remained there for over two years before leaving for Ife. Egharevba opine that Oranmiyan seldom stop an settled in these places to allow his son Eweka's growth in the land of his mother. Perhaps, Oranmiyan felt Odudua will send him to Benin if he knows he left the place without an heir. After Oranmiyan's stay of about three years in Ile-Ife, he left for Oyo, where he also left a son behind on leaving the place. ${ }^{61}$

According to Egharevba's narration, Olobbah was one of the followers of Oranmiyan from Ife who later founded Obbah near Akure, where Oranmiyan halted on his return journey from Benin to Ife. Akure had not then come into existence as a town. At that time, this land was known as Ile.

\footnotetext{
${ }^{57}$ J. Egharevba, A Short History of Benin, $5^{\text {th }}$ edition, Ibadan: University Press, 1966

${ }^{58}$ Ibid

${ }^{59} \mathrm{Ibid}$

${ }^{60}$ J. Egharevba, A Short History of Benin...

${ }^{61} \mathrm{Ibid}$
} 


\section{Critique and Conclusion}

The concept of rain and dove as the earth's process of creation seems more like a fiction than truth. The Yoruba race is archaeologically not more than 2000 years old, which means that before the advent of the Oduduwa, there were other tribes who inhabited that geographical location. ${ }^{62}$ This perhaps will make-strong the version of Samuel Johnson, where he indicated that Oduduwa met an established society when he got to the present day Ile-Ife with his brothers. The Yorubas according to him sprung from Lamurudu one of the kings of Mecca whose offspring were: Oduduwa, the ancestor of the Yorubas, the Kings of Gogobiri and of the Kukawa (two tribes in the Hausa country). It is worthy of remark that these two nations, notwithstanding the lapse of time since their separation and in spite of the distance from each other of their respective localities, still have the same distinctive tribal marks on their faces, and Yoruba travellers are free amongst them and vice versa, each recognising each other as of one blood. ${ }^{63}$

At what period of time Lamurudu reigned is unknown but from the accounts given of the revolution among his descendants and their dispersion, it appears to have been a considerable time after Prophet Mohamed (S.A.W). ${ }^{64}$ The narration from the Oba of Benin although pointed to the fact that the Yoruba history didn't start with the emergence of Oduduwa, and that the Yoruba civilization isn't superior or originate that of the Benin, he however could not adequately indicate where the Edos' originated from.

Going by Omoregie's narrative, Oranmiyan is the direct descendant of Ogiso Owodo, (the last of the Ogiso dynasty), hence, distancing him from the narrative and link with the Yoruba race. ${ }^{65}$ This perhaps is why most Benin scholars ${ }^{66}$ prefer his narrative to that of Jacob Egharevba. ${ }^{67}$ Benson Osadolor have opined that the position of Jacob Egharevba on the Benin-Yoruba history was based on Egharevba's personal relationship and research collaborations which he had while working under Samuel Johnson. ${ }^{68}$ This according to him explains why his narration is subjective; the kind of experience Thucydides had in his writing of the Peloponnesian war between Greece and Athens. ${ }^{69}$

From the narrations of Egharevba and Johnson, it could be deduced that:

- At a point in Benin and Yoruba History, there was need for a political collaboration. Pointing from Egharevba's position that the Benin elders approached Odudua for a leader who ruled them at a particular time; Oranmiyan.

- A certain notable Oba of Benin; Eweka I, is the direct descendant of Oranmiyan.

- Egharevba posits that Oranmiyan left Ile Ife at the command of his father to rule Benin, thereby tallying with Johnson's narrative that Oranmiyan also at a point in time left Oyo in the hands of his eldest son Ajaka to establish new land.

\footnotetext{
${ }^{62}$ F. Willett., 'Ife and its Archaeology', Journal of African History Vol. 1, (2), 1960

${ }^{63}$ S. O. Johnson., The History of the Yorubas, London: Lowe and Brydone Printers Limited, 1921

${ }^{64} \mathrm{Ibid}$

${ }_{65}$ O. S. B. Omoregie., Great Benin 5: The Age of Ikaladerhan (1130-1200 AD), Benin: Neraso Publishers Limited, 1997, see also O. S. B. Omoregie., Benin under the Ogiso Monarchy, (Benin City: Neraso Publishers Limited, 1988)

${ }^{66}$ C. O. Ugowe., Benin in World History, (Lagos: Kosayaz Nigeria Limited.1997), M. Ediagbonya. An Analysis of The Traditions of Origin of Ughoton: the Seaport of Old Benin Kingdom. International Journal of Trade and Policy, Vol. 1 (7) 2018

${ }^{67}$ J. Egharevba., A Short History of Benin, $5^{\text {th }}$ edition, Ibadan: University Press, 1966

${ }^{68}$ O. S. Osadola, M. Ediagbonya, \& S. O. Soetan, Benin-Ekiti Relation: An Onus Of Substantiation, Global Scientific Journal, Vol. 7, Issue 2, 2019, 403-414

${ }^{69}$ H. E. Barnes, A History of Historical Writing, Dover Publications, Inc. 1963
} 
- Both Egharevba and Johnson's narrative seem to agree that Oranmiyan left a son behind in Oyo when he left for the new land. However, Egharevba's narration didn't specifically mention the name of Oranmiyan's son who took the regent role, compared to Johnson's position.

- Johnson and Egharevba both agreed that the remains of Oranmiyan were buried at Ile-Ife or a part in Yoruba land and not Benin.

- There had not been any record of wars between the Yorubas and the Benins in time and space giving credence to the socio-cultural relationship that existed in previous years among them. Example of Benin's political influence in North-eastern Yoruba-lands during the reign of Ewuare could be cited while explaining this bond.

However, both historical versions from Oba of $\mathrm{Benin}^{70}$ and from the Yorubas ${ }^{71}$ accepted that Oranmiyan; Oduduwa's last grandson, indeed returned from Benin to Ife after he had installed his son; Eweka I, as the Oba of Benin after he was dissatisfied with the strange territory. He met Oduduwa, his father who was very old and blind. In addition, all property was shared and distributed among his brothers and sisters. Alternatively, Oduduwa was at a dilemma, according to Oba of Benin, since he thought the Kingdom of Benin would be an adequate legacy for Oranmiyan. But both historical versions accepted that the name Benin meant "the land of vexation" (Ile-Ibinu), as Oranmiyan left the place annoyed.

Going by the above facts, the question of tracing the origins of the Benin people is now almost related to views and interpretations about the Benin-Ife connection. This perhaps made it even more difficult to grasp the historical facts that existed between Benin's origins and the origins of the Eweka dynasty. Egharevba had posited in book ${ }^{72}$ that the Binis were migrants from Egypt to Ile-Ife. Although Benin-historical interpretations of Ife can still upset fresh information, comprehending the facts and reasoning only explains the foundations of the Eweka dynasty and not the people. Ryder cautions that some of the information that European visitors to Benin have gathered from the 15th century is not readily reconciled to clashing traditions in Benin-Ife. ${ }^{73}$

Oranmiyan was invited to take over his father's work, which was largely ceremonial and voodoo, as well as traditional ruler of Ile Ife, following the death of Oduduwa. Oranmiyan declined because he had established an economically viable community at Oyo-Ile with an administratively sound system of government centered on the Oyo-mesi council in chief. It would be extremely degrading to abandon and relocate to Ile-Ife in order to perform regular ritual sacrifices. Oranmiyan stipulated that he must be buried at Ife to symbolize his right to the Ife tossed. Ooni, Oduduwa's assistant in the regular ceremonial sacrifice exercise, continued to do Odua's job while he (Oranmiyan) continued to work under the supervision of Oyo Ile. Ooni (the son of the slave woman who was

\footnotetext{
${ }^{70}$ Omo N' Oba, Erediauwa, I Remain, Sir, Your Obedient Servant, (Spectrum Books Publisher, 2004)

71 Johnson, S.O., (1921) The History of the Yorubas, London: Lowe and Brydone Printers Limited, 1921, see also, J. A. Atanda., An introduction to Yoruba History, (Ibadan, University Press, 1980),

72 J. Egharevba., A Short History of Benin, $5^{\text {th }}$ edition, Ibadan: University Press, 1966

${ }^{73}$ A. F. Ryder., Benin and the Europeans 1485-1897, (London: Longman 1969) see also, S. O. Biobaku., Sources of Yoruba History, New York: Clarendon Press, 1973
} 
rescued and prayed to the gods for assisting Oduduwa) resumed Oduduwa's work at Ife on that basis. This is why Alaafin of Oyo might never recognize Ooni of Ife as a superior king at any Yoruba Obas meeting. ${ }^{74}$

Ooni's supposed supremacy was a British invention, based on the belief that the king of Ile-Ife (the birthplace of Yoruba) would be superior to all Obas. The abdication of the throne results in Oranmiyan ceding his right to his son in Benin. The fact that Eweka and his descendants continue to honour tradition by being buried in Ife or receiving blessings before being crowned (at a point in time) made it easier to deduce that Ile-Ife is most likely superior to Benin and maybe the Edos derived their origin from there. ${ }^{75}$

The origins of the Yorubas from Benin seemed to be entirely credible as provided by Oba Eredua, ${ }^{76}$ it appears more authentic than the Saudi Arabia or Lamurudu narrations, which are not traceable in Saudi Arabian history. ${ }^{77}$ However, the truth or tradition of the Oba of Benin's loyalty to Ile Ife (the cradle of the Yoruba race) both before and after his coronation indicates that Ife may be the root of both the Yoruba and the Edo races.

The burial of Oranmiyan at Ile-Ife and Oranmiyan Symbolic Staff (Opa Oranmiyan) by his grandfather Oduduwa was designed to demonstrate his right to Oduduwa's throne or seat. Ooni is most likely not an Oduduwa descendent; hence he may not be related to the 16 grandchildren of Oduduwa. The initial payment of Ooni's homage to Alaafin Oyo was also a reference to the fact that Ooni is identical to all the other Kings who were created during expansion from Ile-Ife.

\footnotetext{
${ }^{74}$ N. A. Fadipe., Sociology of the Yorubas, Ibadan: Ibadan University Press, 1970

${ }^{75}$ A. E. Afigbo., "The Benin Mirage and the History of South Central Nigeria." Nigeria daily Magazine, no. 137, 1998

${ }^{76}$ Omo N' Oba, Erediauwa, I Remain, Sir, Your Obedient Servant, (Spectrum Books Publisher, 2004)

77 S.O. Johnson, The History of the Yorubas, London: Lowe and Brydone Printers Limited 1921 p. 144
} 